\title{
Characterisation and concentration profile of aluminium during drinking-water treatment
}

\author{
PT Srinivasan ${ }^{1}$ and T Viraraghavan ${ }^{2 *}$ \\ ${ }^{1}$ Staff Engineer, ARCADIS G \& M Inc., Chicago, IL, USA 60601 \\ ${ }^{2}$ Professor Emeritus, Faculty of Engineering, University of Regina, Regina, Canada S4S OA2
}

\begin{abstract}
An aluminium(Al) characterisation study was conducted at a surface water treatment plant (Buffalo Pound Water Treatment Plant (BPWTP) in Moose Jaw, Saskatchewan, Canada) to understand better the effect of alum coagulant on various Al fractions. The raw water source for BPWTP is Buffalo Pound Lake water. The Al sources at BPWTP are:

- present naturally $\mathrm{Al}$ in the raw water and

- Al derived due to use of alum as a coagulant.

Seasonal evaluations of Al at BPWTP showed that raw lake water total concentrations were highly variable. Suspended (filterable) $\mathrm{Al}$ was the predominant species of raw water total $\mathrm{Al}$. Organic-bound or organo- $\mathrm{Al}$ complex $\mathrm{Al}$ appeared to be the predominant species of dissolved Al in both raw and treated water during the September to November $1997 \mathrm{Al}$ characterisation study. However, during October to December 1998, inorganic Al dominated dissolved Al content. Characterisation of Al at BPWTP showed that the use of (liquid) $\mathrm{Al}$ sulphate (alum) did not increase the concentration of total $\mathrm{Al}$ levels.

This was because:

- alum coagulation was practised at $\mathrm{pH} 7$, at which the $\mathrm{Al}$ is least soluble

- clarifier and filtration units effectively removed particulate $\mathrm{Al}$ and

- granular activated carbon (GAC) was capable of removing part of the organic dissolved Al.

The study showed that BPWTP would be able to comply with the requirement of Health Canada Guideline value (for conventional treatment plants) for $\mathrm{Al}$ of less than $100 \mu \mathrm{g} / \ell$ as total $\mathrm{Al}$. Turbidity and dissolved organic carbon of the raw water influenced the applied alum dose at BPWTP.
\end{abstract}

\section{Introduction}

The presence of $\mathrm{Al}$ in treated water for distribution has been a subject of concern for many years. Links have been established between $\mathrm{Al}$ in drinking water and human neurological disorders such as dialysis encephalopathy (Parkinson et al., 1979). A recent study by Berend and Trouwborst (1999) showed that excess Al in dialysate fluid was harmful to dialysis patients. Additionally, links in the case of Alzheimer's disease have been proposed (McLachlan et al., 1991). Although much more work is needed before the full implication of the toxic effects of $\mathrm{Al}$ is known, it is generally agreed that the knowledge of the form or type of Al species in the water system is of importance since both bio-availability and toxicity are critically dependent on the chemical form of the individual species of a metal. Speciation or characterisation may be defined as the determination of the individual concentrations of the various chemical forms of an element which together make up the total concentration of that element in a sample. The words "characterisation" and "speciation" are used interchangeably in this paper.

Aluminium which is present in alum and naturally present $\mathrm{Al}$ in raw water are transformed into various forms during water treatment. The literature indicates that the use of a coagulant containing $\mathrm{Al}$ may either increase or decrease $\mathrm{Al}$ concentration in the finished water, depending on its speciation in the source water as well as species (change or distribution) of $\mathrm{Al}$ during water treatment and conditions of water treatment. It is reported that when

\footnotetext{
* To whom all correspondence should be addressed.
}

皿1- 306-585 -4094; fax: 1- 306-585-4855;

e-mail: t.viraraghavan@uregina.ca

Received 7 February 2001; accepted in revised form 26 October 2001. alum (i.e $\left.\mathrm{Al}_{2}\left(\mathrm{SO}_{4}\right)_{3} .14 \mathrm{H}_{2} \mathrm{O}\right)$ is used as a coagulant for water treatment there is a $50 \%$ chance that it can lead to increased concentrations of $\mathrm{Al}$ in the treated water compared to the raw water itself (Miller et al., 1984; Driscoll and Letterman, 1987; Driscoll and Letterman, 1988; Driscoll and Letterman, 1995). A high concentration of $\mathrm{Al}(3.6$ to $6 \mathrm{mg} / \ell)$ in the treated water contributes to turbidity, reduced disinfection efficiency, and precipitation of $\mathrm{Al}$ hydroxide within the distribution system. Most water treatment plants measure effluent levels of total or dissolved Al. However, profiles of various forms of Al levels through a water treatment plant are rarely performed. Added to this, few countries set standards (based on aesthetic considerations only) for $\mathrm{Al}$. In addition, $\mathrm{Al}$ is not a routine monitoring parameter in finished water in many water treatment plants. Furthermore, relatively little attention has been paid to the speciation of $\mathrm{Al}$ in raw, treated and distributed waters (AWWA Committee Report, 1993). It is generally accepted that free (hydrated) metal ion is the form which is most toxic to aquatic life. Strongly complexed metal or metal associated with colloidal particles is much less toxic (Florence and Batley, 1980). Hence, determination of the total concentration of a metal in a water sample provides very little information about the toxicity of that water.

Aluminium characterisation was conducted at the Buffalo Pound Water Treatment Plant (BPWTP) which is located approximately $85 \mathrm{~km}$ west of Regina. The plant supplies drinking water to the cities of Regina and Moose Jaw. The raw water source is Buffalo Pound Lake $(29 \mathrm{~km}$ long, and $1 \mathrm{~km}$ wide, with an average depth of $3 \mathrm{~m}$ ), a shallow reservoir in the Qu' Appelle Valley. Raw water from Buffalo Pound Lake passes through a series of unit operations including prechlorination, cascade degassification, coagulation and flocculation, clarification, filtration, and carbon adsorption (during summer months). The plant uses liquid $\mathrm{Al}$ 
sulphate (alum) as coagulant. No polymer is added during coagulation.

The objectives of the present research work were to:

- conduct seasonal Al characterisation (speciation) studies at BPWTP (September to November 1997 and October to December 1998);

- examine the profile of $\mathrm{Al}$ from raw to the treated water and identify the factors influencing profile changes;

- evaluate the Al removal efficiency of major unit operations such as clarifiers/filters at the plant; and

- identify the factors influencing residual $\mathrm{Al}$ in treated water.

\section{Materials and methods}

\section{Materials}

Nalgene 500-m $\ell$ high-density polyethylene (HDPE) bottles were used for water sample collection and storage. Nucleopore polycarbonate $0.45 \mu \mathrm{m}$ membrane filters (Corning Separations Division, Acton, MA 01720) were used for the separation of total and dissolved Al. Filtration of samples was carried out using a vacuum pump and $1 \ell$ polypropylene filtering flasks were used to collect the filtrate. No glass containers were used in order to avoid the problem of $\mathrm{Al}$ leaching. A strongly acidic cation exchange resin, Amberlite IR- 120 plus (sodium form, - 16-50 mesh US standard screens, - Rohm and Hass Company, PA 18105), was used for speciation of dissolved Al. A variable - speed peristaltic pump (E- 07553 - 70 L/S, Cole - Parmer Instrument Company, Ill) was used to pump filtered water into cation column of $1 \mathrm{~cm}$ internal diameter $\times 30 \mathrm{~cm}$ height (C 6169, Sigma Aldrich Canada Ltd).

A Perkin Elmer graphite furnace atomic absorption spectrophotometer (GFAAS) (2380 Spectrophotometer, - HGA 400 furnace with $\mathrm{D}_{2}$ arc background corrector and AS 40 auto sampler) was used for measurement of Al present in water samples during both phases of Al characterisation study at BPWTP. Standard Al solutions $(10,30,50,80$ and $100 \mu \mathrm{g} / \ell)$ were prepared by diluting Anachemia AAS grade Al reference (stock) solution of $997 \mu \mathrm{g} / \mathrm{l}$ for calibration of GFAAS. Magnesium nitrate $(0.1 \%)$ was used as a matrix modifier for the measurement of Al by GFAAS. All chemicals used were of ACS reagent grade. Distilled-deionised water was used for dilution of stock solutions as well as for any reagent preparation. All containers used in this study were cleaned using distilled-deionised water, as follows:

- cleaned with $1+1 \mathrm{HCl}$ and then stored in $1+1 \mathrm{HCl}$ for $12 \mathrm{~h}$;

- rinsed with distilled-deionised water and then stored in distilled deionised water for $12 \mathrm{~h}$; and

- rinsed with distilled-deionised water.

It is reported that membrane filters were used freshly and the first $50 \mathrm{~m} \ell$ of sample was avoided to prevent any contamination due to filters.

\section{Method selection for speciation of drinking water Al}

The speciation method developed by Driscoll and Letterman (1995) was adopted in the present study with some changes. Water samples during this speciation experiment were given the same pretreatment (acid digestion, $0.45 \mu \mathrm{m}$ membrane filter separation and cation exchange resin treatment) as proposed in Letterman and Driscoll(1994), but oxine-methylisobutyl ketone(MIBK) extraction was not used, as indicated in Driscoll and Letterman (1995) - instead pretreated samples were analysed for Al by GFAAS. Digestion procedure (for total/dissolved plus colloidal Al) involved lowering sample $\mathrm{pH}$ to 1 using trace metal grade nitric acid (A 509B- 500 Fisher) and keeping the sample at $\mathrm{pH}=1$ for $2 \mathrm{~h}$ before measurement. A detailed method development related to measurement of drinking water Al using GFAAS along with interlaboratory quality control and method validation that were part of the Al speciation study can be found elsewhere (Srinivasan et al., 2000).

\section{Assumptions involved in the present Al speciation protocol}

- Filtration of samples through $0.45 \mu \mathrm{m}$ membrane filters removes filterable (suspended) $\mathrm{Al}$ and does not remove colloidal particles or dissolved $\mathrm{Al}$.

- Acid digestion step solubilises all the colloidal Al present in the sample.

- After the samples were pretreated, the samples were measured for Al using a GFAAS (instead of the conventional oxine extraction used in Al speciation study) since the authors' extensive preliminary work demonstrated that the time of extraction, sample $\mathrm{pH}$, extraction $\mathrm{pH}$, and the order of adding reagents during oxine extraction influence the oxine extraction results very much. A recent work by Allan (1997) involving Al speciation study in Whetstone Brook in western Massachusetts; and an $\mathrm{Al}$ speciation protocol developed by Berube and Brule (1994) of Health Canada for the speciation of Al present in shallow wells of Atlantic Provinces of Region of Canada using inductively coupled plasma-mass spectrometry (ICP-MS) did not use the oxine extraction step.

- The capability of the graphite furnace to detect colloidal-bound $\mathrm{Al}$ lies in the fact that the acid solubilisation improves the furnace performance in atomising the samples effectively, leading to a difference in value between acidified and nonacidified sample values. Bloom and Erich (1989) suggested that even at high temperatures, minerals-bound colloidal $\mathrm{Al}$ is not decomposed during atomisation, whereas acid solubilisation ameliorates the sample decomposition.

- The sum of filterable (suspended) and colloidal Al concentrations provides particulate Al concentration according to this Al speciation protocol. Colloidal Al can be associated with colloidal particles/clay of various size ranges (which is essentially a part of filterable (suspended) form of $\mathrm{Al}$ ); but a $0.45 \mu \mathrm{m}$ membrane filter can let colloidal Al pass through it. However, subsequent acid solubilisation releases this $\mathrm{Al}$ to the sample environment. Hence, Al retained by a $0.45 \mu \mathrm{m}$ membrane filter (filterable or suspended $\mathrm{Al}$ ) and $\mathrm{Al}$ passed through a $0.45 \mu \mathrm{m}$ membrane filter (colloidal $\mathrm{Al}$ ) are added to get particulate Al.

\section{Protocol for characterisation of Al}

Al was fractionated into eight different forms. Filters have "self adsorption/absorption" capacity for $\mathrm{Al}$ and, hence, initial filtrates would not have the same $\mathrm{Al}$ content as samples. After discarding the initial filtrate volume of 30 to $40 \mathrm{~m} \ell$, samples ( $30 \mathrm{~m} \ell$ volume) were collected for $\mathrm{Al}$ analysis. The different forms were as follows:

- Total $\mathrm{Al}\left(\mathrm{Al}_{\mathrm{T}}\right)$ (acidification of samples at room temperature at $\mathrm{pH} 1$ for $2 \mathrm{~h})$.

- Colloidal and dissolved $\mathrm{Al}\left(\mathrm{Al}_{(\mathrm{C}+\mathrm{D})}\right)$ (sample filtered through $0.45 \mu \mathrm{m}$ polycarbonate membrane filter, and acidified to $\mathrm{pH} 1$ for $2 \mathrm{~h}$ ). 
- Dissolved (inorganic and organic) $\mathrm{Al}$ $\mathrm{Al}_{(\mathrm{I}+\mathrm{O})}$ (sample filtered through $0.45 \mu \mathrm{m}$ polycarbonate membrane filter but not acidified).

- Organic $\mathrm{Al}\left(\mathrm{Al}_{\mathrm{o}}\right.$ ) (organo Al complexed with NOM) - a strongly acidic cation exchange resin of Amberlite IR 120 Plus, was used to fractionate dissolved Al into two fractions, namely, inorganic and organically-bound $\mathrm{Al}$; $\mathrm{Al}$ complexed by the inorganic ligands such as hydroxide, fluoride, sulphate and silicate (known as inorganic Al) was removed (i.e., exchanged for sodium or hydrogen ion present in the resin) and organic $\mathrm{Al}$ was not removed; filtered water sample is passed through cation exchange resin and effluent was analysed without any acidification for organically-bound Al.

- Filterable (suspended) $\mathrm{Al}\left(\mathrm{Al}_{\mathrm{ss}}\right.$ ) was estimated as the difference between $\left(\mathrm{Al}_{\mathrm{T}}\right)-\left(\mathrm{Al} \mathrm{C}_{(\mathrm{C}+\mathrm{D})}\right)$.

- Colloidal $\mathrm{Al} \mathrm{Al}_{\mathrm{C}}$ was estimated as the difference between $\left(\mathrm{Al}_{(\mathrm{C}+\mathrm{D})}\right)-\left(\mathrm{Al}_{(\mathrm{I}+\mathrm{O})}\right)$ dissolved fraction.

- Total particulate $\mathrm{Al}\left(\mathrm{Al}_{\mathrm{TP}}\right)$ was estimated as the sum of $\left(\mathrm{Al}_{\mathrm{sS}}\right)$ and $\left(\mathrm{Al}_{\mathrm{c}}\right)$.

- Inorganically-bound $\mathrm{Al}\left(\mathrm{Al}_{\mathrm{I}}\right)$ was estimated as the difference between dissolved $\mathrm{Al} \mathrm{Al}_{(\mathrm{I}+\mathrm{O})}$ and organically bound $\mathrm{Al}\left(\mathrm{Al}_{\mathrm{o}}\right)$. Table 1 shows the various $\mathrm{Al}$ fractions obtained during the present study.

Analytical methods used in this study for the measurement of other water quality parameters such as $\mathrm{pH}$, sulphate, fluoride, and dissolved organic carbon (DOC) are shown in Table 2. A schematic diagram of BPWTP and locations at which samples were collected for speciation of $\mathrm{Al}$ are shown in Fig.1.

\section{Cation column studies}

The cation exchange column used in this study was a chromatography column of $1 \mathrm{~cm}$ internal diameter by $30 \mathrm{~cm}$ height filled with a $10 \mathrm{~m} \ell$ of sodium form of Amberlite IR 120 Plus, a strongly acidic cation-exchange resin. Letterman and Driscoll (1994) reported that the $\mathrm{pH}$ change when samples are processed through the cation-exchange column has to be minimal. If the $\mathrm{pH}$ change is significant, equilibrium between organic and inorganic $\mathrm{Al}$ species will be disturbed and will eventually lead to competition between hydrogen ion and $\mathrm{Al}$ for dissolved organic matter present in water. This may lead to incorrect measurement of either the organic or inorganic fraction of dissolved Al. The $\mathrm{pH}$ of the samples before and after the column during this study indicated that insignificant $\mathrm{pH}$ changes occurred. Results of cation exchange columns are also influenced by flow rate through the column. Optimum flow rate $(20 \mathrm{~m} / \mathrm{min})$ as recommended by Letterman and
TABLE 1

Aluminium fractions obtained during the present study

\begin{tabular}{|c|c|c|c|c|}
\hline \multirow[t]{2}{*}{ Description } & \multicolumn{3}{|c|}{ Pretreatment } & \multirow{2}{*}{$\begin{array}{c}\text { Fraction } \\
\text { groups } \\
\text { determined } \\
\text { by difference }\end{array}$} \\
\hline & Acidification & $\begin{array}{l}\text { Filtration } \\
(0.45 \mu \mathrm{m})\end{array}$ & $\begin{array}{c}\text { Cation } \\
\text { exchange }\end{array}$ & \\
\hline 1. Total Al & Yes & & & \\
\hline $\begin{array}{l}\text { 2. Colloidal + } \\
\text { Dissolved Al }\end{array}$ & Yes & Yes & & \\
\hline 3. Dissolved Al & & Yes & & \\
\hline 4. Organic Al & & & $\begin{array}{c}3 \text { through } \\
\text { cation resin } \\
\text { (removes } \\
\text { inorganic } \mathrm{Al})\end{array}$ & \\
\hline $\begin{array}{l}\text { 5. Filterable } \\
\text { (suspended) Al }\end{array}$ & & & & $1-2$ \\
\hline 6. Colloidal Al & & & & $2-3$ \\
\hline 7. Particulate Al & & & & $5+6$ or $1-3$ \\
\hline 8. Inorganic $\mathrm{Al}$ & & & & $3-4$ \\
\hline
\end{tabular}

TABLE 2

Analytical methods/instruments used in this study

\begin{tabular}{|c|c|c|}
\hline Test & Method/instrument & Reference \\
\hline $\mathrm{pH}$ & Orion SA $720 \mathrm{pH}$ meter & Operation manual \\
\hline Alkalinity & $\mathrm{HCl}$ titration & Standard Methods, 1995 \\
\hline $\begin{array}{l}\text { Dissolved organic } \\
\text { carbon }\end{array}$ & $\begin{array}{l}\text { Astro } 2001 \text { System II Carbon } \\
\text { Analyzer }\end{array}$ & $\begin{array}{l}\text { Operations Manual, } \\
\text { Standard Methods, } 1995\end{array}$ \\
\hline Particle count & $\begin{array}{l}\text { HIAC model PC }-320 \\
\text { automatic particle size analyzer }\end{array}$ & Operation manual \\
\hline Silica & Spectrophotometer & Standard Methods, 1995 \\
\hline Fluoride & $\begin{array}{l}\text { Orion fluoride electrode- orion } \\
\text { Model } 701 \mathrm{~A} \text {, digital ion-analyzer }\end{array}$ & Standard Methods, 1995 \\
\hline Conductivity & $\begin{array}{l}\text { Horiba Model DS- } 12 \text { conductivity } \\
\text { meter }\end{array}$ & Operation manual \\
\hline Hardness & EDTA titration & Standard Methods, 1995 \\
\hline $\begin{array}{l}\text { Chloride and } \\
\text { sulphate }\end{array}$ & $\begin{array}{l}\text { Ion chromatography } \\
\text { (Dionex } 2000 \text { i/ SP) }\end{array}$ & Standard Methods, 1995 \\
\hline Turbidity & НACH 2001 & Standard Methods, 1995 \\
\hline
\end{tabular}

Driscoll (1994) was used throughout the experiments. Dissolved organic carbon of the influent to the cation-exchange column should be equal to dissolved organic carbon of the cation resin treated water, i.e, cation exchange column from a chemistry point of view should not remove any dissolved organic carbon. However, organic carbon may leach from the resin itself. This was verified by running a UV scan (pattern) from $220 \mathrm{~nm}$ to $360 \mathrm{~nm}$ (Standard Methods, 1995). According to Standard Methods (1995), typical 


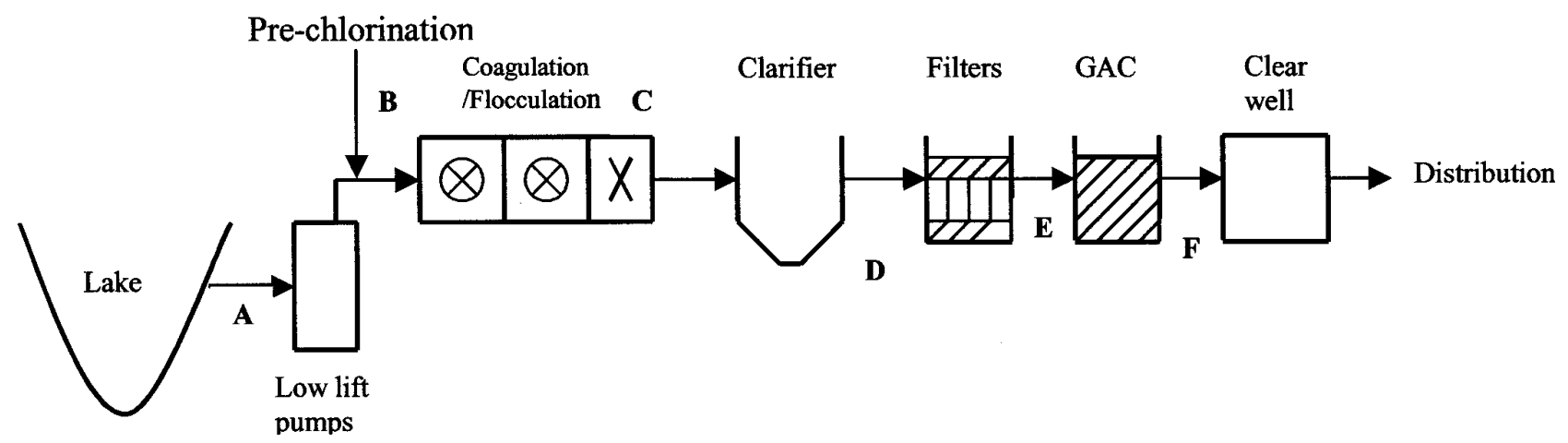

Figure 1

Schematic diagram of the BPWTP and sampling locations for Al speciation

TABLE 3

Average raw and treated water (Clear Well - Regina) characteristics of BPWTP during the speciation study

\begin{tabular}{|l|l|c|c|}
\hline Parameter & Unit & $\begin{array}{c}\text { Raw } \\
\text { water }\end{array}$ & $\begin{array}{c}\text { Treated } \\
\text { water }\end{array}$ \\
\hline $\mathrm{pH}$ & $\mathrm{pH}$ units & 8.3 & 7.3 \\
Alkalinity & $\mathrm{mg} / \ell$ as $\mathrm{CaCO}_{3}$ & 153 & 120 \\
Hardness & $\mathrm{mg} /$ as $\mathrm{CaCO}_{3}$ & 181 & 181 \\
Dissolved organic carbon* & $\mathrm{mg} / \ell$ & & \\
Fluoride & $\mathrm{mg} / \ell$ & 0.18 & 0.11 \\
Sulphate & $\mathrm{mg} / \ell$ & 119 & 146 \\
Silica** & $\mathrm{mg} / \ell$ & & \\
Chloride & $\mathrm{mg} / \ell$ & 16 & 19 \\
Particles & $\mathrm{per} \mathrm{m} \ell$ & 31150 & 24 \\
Conductivity & $\mu \mathrm{S} / \mathrm{cm}$ & 583 & 602 \\
Temperature & ${ }^{\circ} \mathrm{C}$ & 4 & 4 \\
Turbidity & $\mathrm{NTU}$ & 6.5 & 0.1 \\
\hline
\end{tabular}

$*$ (Sept. to Nov. 1997 , Raw $=8.8$, Treated $=3.6)($ Oct. to Dec. 1998 , Raw $=8.4$, Treated $=5.3$ )

$* *$ (Sept. to Nov. 1997, Raw $=6.2$, Treated $=5.7)($ Oct. to Dec. 1998 , Raw $=0.72$, Treated $=0.8$ ) absorbance scans of natural organic matter are featureless curves of increasing absorbance with decreasing wavelength. Sharp peaks or irregularities in the absorbance scan may be indicative of inorganic interferences or unexpected organic contaminants (e.g. leaching of organic carbon). In the present study, the authors analysed UV absorbance patterns for raw (before column) and cation - exchange treated water between $220 \mathrm{~nm}$ to $360 \mathrm{~nm}$. This was a featureless curve (no sharp peaks) and absorbance increased with decreasing wavelength. This indicated that no organic carbon leached from the resin.

\section{Results and discussion}

Average raw and treated water (clear well - Regina) characteristics of BPWTP during the Al characterisation study period are shown in Table 3 . Table 4 shows the mean $\mathrm{Al}$ fractions (in $\mu \mathrm{g} / \ell$ ) obtained through the plant during September to November 1997 and October to December 1998 at the BPWTP. Table 5 shows the associated standard deviations for various $\mathrm{Al}$ fractions reported in Table 4. Figure 2 shows the total, particulate, and filterable (suspended) $\mathrm{Al}$ profiles obtained (on logarithmic scale) at BPWTP from raw water to the treated water. Figure 3 shows the profiles of colloidal + dissolved, dissolved, inorganic, organic and colloidal Al obtained at BPWTP from raw water to the treated water. Tables 6 and 7 respectively present the $\mathrm{Al}$ data pertaining to mean total, organic, inorganic and colloidal $\mathrm{Al}$ values for September to November 1997 and October to December 1998 periods individually in order to explain some of the trends observed in these $\mathrm{Al}$ values.

\section{Particulate Al removal/ dissolved Al formation and its characteristics}

It was observed during the entire $\mathrm{Al}$ characterisation period that consistently good removal of particulate $\mathrm{Al}$ (an average of $92 \%$ particulate $\mathrm{Al}$ 


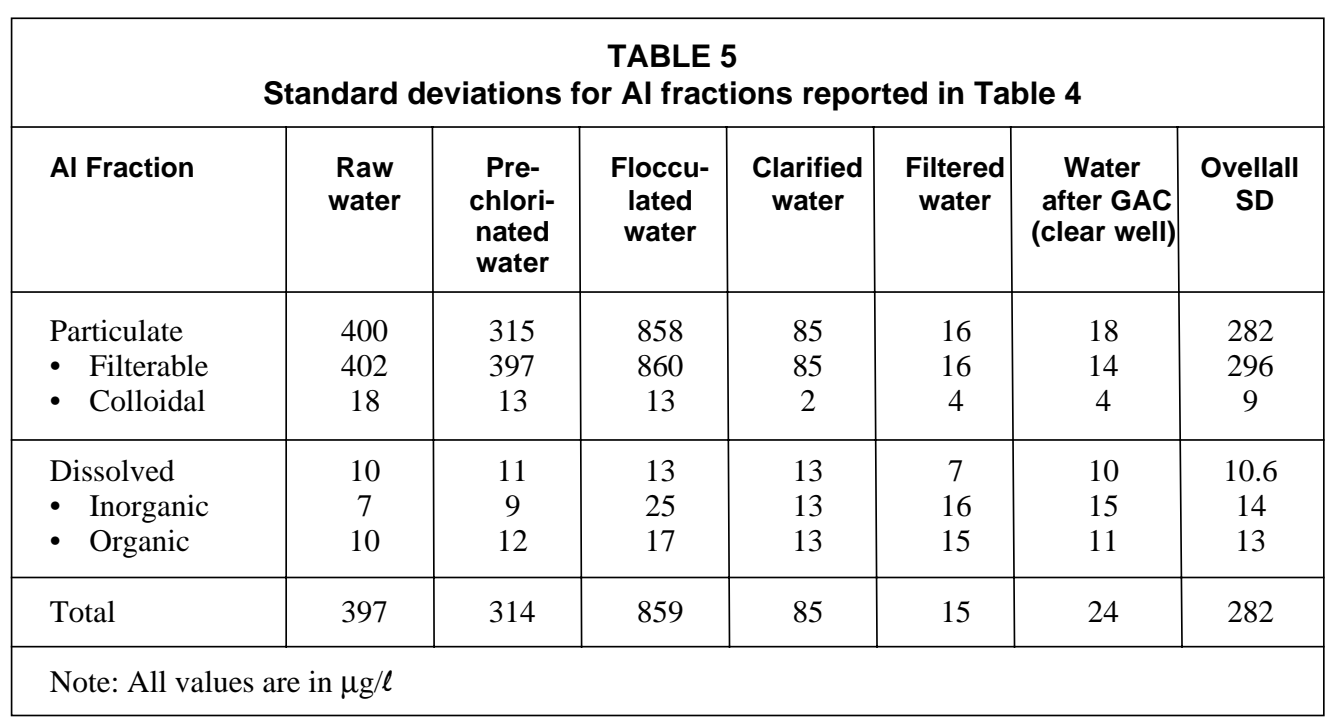

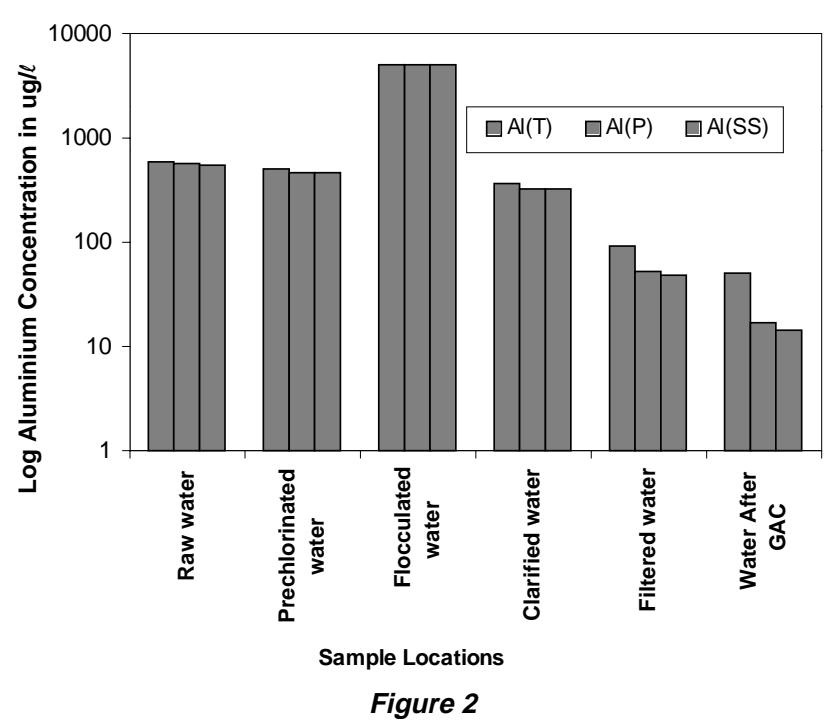

Profiles of total, particulate, and filterable Al obtained during the Al characterisation study period (on logarithmic scale) at BPWTP

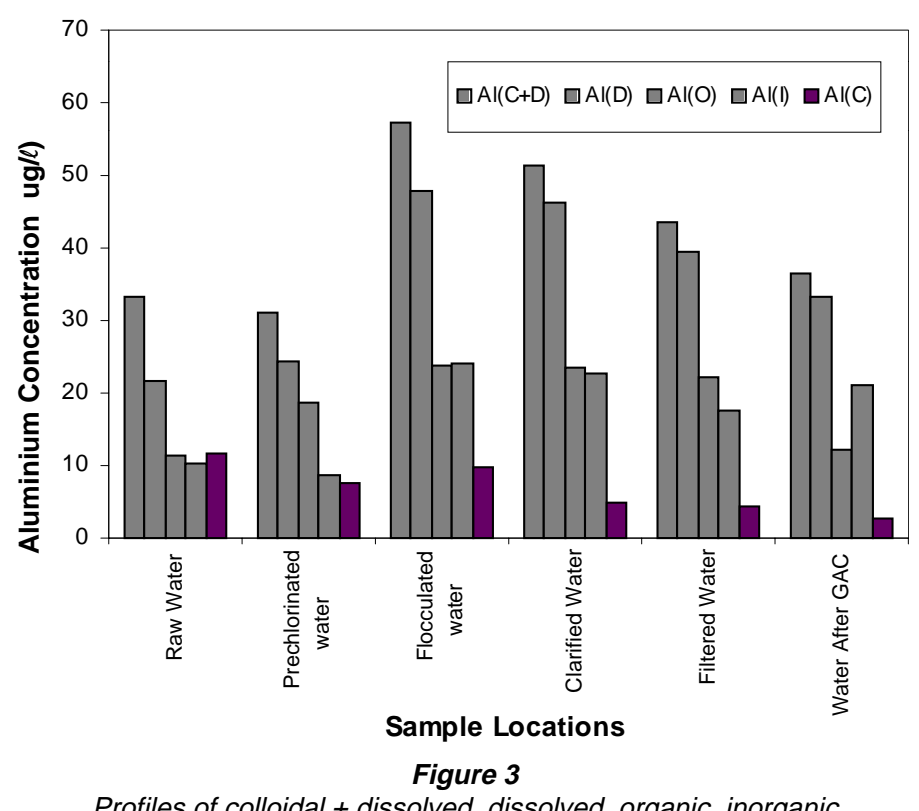

Profiles of colloidal + dissolved, dissolved, organic, inorganic and colloidal Al obtained during the Al characterisation study period at BPWTP was precipitated as $\mathrm{Al}(\mathrm{OH})_{3}$ and removed as sludge) was observed at the clarifier (Channel I) and an average of $85 \%$ of particulate $\mathrm{Al}$ was further removed by sand filtration (Table 4).

Dissolved Al levels rose prior to filtration and alum was responsible for such an increase in dissolved $\mathrm{Al}$ by virtue of its hydrolysis products (Fig. 3). Dissolved Al increased from $22 \mu \mathrm{g} / \ell$ to $48 \mu \mathrm{g} / \ell$ due to alum addition (Fig. 3). However, sedimentation, filtration and $\mathrm{GAC}$ following alum addition decreased dissolved $\mathrm{Al}$ to 32 to $33 \mu \mathrm{g} / \ell$ in treated water (Table 4 and Fig. 3 ).

Comparison of the mean dissolved inorganic $\mathrm{Al}$ value before and after alum addition indicated that alum addition increased nearly three times ( 9 to $24 \mu \mathrm{g} / \ell$ ) the dissolved inorganic $\mathrm{Al}$ (Fig. 3). There was a $5 \mu \mathrm{g} / \ell$ increase in organic $\mathrm{Al}$ due to alum addition and its levels remained relatively constant at channel $(24 \mu \mathrm{g} / \ell)$ and sand filters $(22 \mu \mathrm{g} / \ell)$. However, in finished water, the organic $\mathrm{Al}$ value was reduced to 12 to $15 \mu \mathrm{g} / \ell$, implying the capability of GAC to remove part of dissolved $\mathrm{Al}$ in organic form (Table 4).

\section{Characterisation and variations in total $\mathrm{Al}$ at the BPWTP raw water}

Al characterisation studies showed that raw lake water total Al concentrations were highly variable (262 to 1189 $\mu \mathrm{g} / \ell)$ during the September to November 1997 period (Table 6). This variability could be due to the fact that high wind and rain occurred during some of the days of sampling, altering water quality characteristics of influent to the treatment plant. It can be seen from Fig. 2 that almost all raw water particulate $\mathrm{Al}$ (predominant species of total $\mathrm{Al}$ ) was present in filterable (suspended) form. An Al speciation study by Letterman and Driscoll (1994) at three water treatment plants and an Al speciation study by Van Benschoten and Edzwald (1990) at two water treatment plants showed that particulate $\mathrm{Al}$ was the dominant species in raw water total Al. Benes et al. (1976) who analysed metal contents present in a freshwater lake also reported that much of the $\mathrm{Al}$ was present in particulate form. Particulate form of $\mathrm{Al}$ continued to be the dominant form in total Al until the raw water passed through the channel (clarifier) of the plant (Fig. 2). The mean raw water total Al concentration increased nearly seven times due to alum addition during the September to November $1997 \mathrm{Al}$ characterisation study period (Table 6). 


\begin{tabular}{|c|c|c|c|c|c|c|}
\hline \multicolumn{7}{|c|}{$\begin{array}{c}\text { TABLE } 6 \\
\text { Mean total, organic, inorganic and colloidal Al values of Al characterisation } \\
\text { study period Sept. to Nov. } 1997\end{array}$} \\
\hline Al fraction & $\begin{array}{c}\text { Raw } \\
\text { water }\end{array}$ & $\begin{array}{l}\text { Pre- } \\
\text { chlori- } \\
\text { nated } \\
\text { water }\end{array}$ & $\begin{array}{l}\text { Floccu- } \\
\text { lated } \\
\text { water }\end{array}$ & $\begin{array}{l}\text { Clarified } \\
\text { water }\end{array}$ & $\begin{array}{l}\text { Filtered } \\
\text { water }\end{array}$ & $\begin{array}{l}\text { Water } \\
\text { after GAC } \\
\text { (clear well) }\end{array}$ \\
\hline Total & $\begin{array}{c}830 \\
*(262-1189)\end{array}$ & 670 & 5758 & 301 & 85 & 32 \\
\hline Organic & 9 & 24 & 40 & 29 & 30 & 19 \\
\hline Inorganic & 7 & 2 & 6 & 13 & 6 & 5 \\
\hline Colloidal & 17 & 1.2 & 3.5 & 20 & 5.9 & 0.8 \\
\hline \multicolumn{7}{|c|}{$\begin{array}{c}\text { Note: } * \text { Value in bracket is range } \\
\text { All values are in } \mu \mathrm{g} / \ell\end{array}$} \\
\hline
\end{tabular}

\begin{tabular}{|c|c|c|c|c|c|c|}
\hline \multicolumn{7}{|c|}{$\begin{array}{c}\text { TABLE } 7 \\
\begin{array}{c}\text { Mean total, organic, inorganic and colloidal Al values of Al characterisation } \\
\text { study period October to December } 1998\end{array}\end{array}$} \\
\hline Al fraction & $\begin{array}{l}\text { Raw } \\
\text { water }\end{array}$ & $\begin{array}{l}\text { Pre- } \\
\text { chlori- } \\
\text { nated } \\
\text { water }\end{array}$ & $\begin{array}{l}\text { Floccu- } \\
\text { lated } \\
\text { water }\end{array}$ & $\begin{array}{l}\text { Clarified } \\
\text { water }\end{array}$ & $\begin{array}{c}\text { Filtered } \\
\text { water }\end{array}$ & $\begin{array}{c}\text { Water } \\
\text { after GAC } \\
\text { (clear well) }\end{array}$ \\
\hline Total & $\begin{array}{c}380 \\
*(180-600)\end{array}$ & 354 & 4576 & 427 & 102 & 65 \\
\hline Organic & 14 & 15 & 11 & 19 & 12 & 7 \\
\hline Inorganic & 13 & 14 & 39 & 31 & 32 & 33 \\
\hline Colloidal & 7.2 & 12.7 & 14.3 & 5.0 & 2.2 & 3.6 \\
\hline \multicolumn{7}{|c|}{$\begin{array}{c}\text { Note: } * \text { Value in bracket is range } \\
\text { All values are in } \mu \mathrm{g} / \ell\end{array}$} \\
\hline
\end{tabular}

During October to December 1998 the raw water had a mean total $\mathrm{Al}$ of $380 \mu \mathrm{g} / \ell$ compared to a mean value of $830 \mu \mathrm{g} / \ell$ for September to November 1997 (Tables 6 and 7). This indicated that the total $\mathrm{Al}$ was highly variable between the two study periods. It was interesting to note that a comparison of raw and treated water characteristics indicates that during October to December 1998 raw water silica content (Table 3$)$ was much less $(0.72 \mathrm{mg} / \ell)$ than during September to November 1997 (6.2 mg/ $/$ ) implying that soil - bound $\mathrm{Al}$ silicate may be less available to contribute to raw water $\mathrm{Al}$, and, therefore, lower raw water total $\mathrm{Al}$ values were observed during 1998. These variations in total $\mathrm{Al}$ are not surprising because Al concentration can be a very dynamic parameter in treated drinking water and can change quite rapidly with changes in raw water quality or with plant upsets or operational changes (Health Canada, 1996). Raw water total $\mathrm{Al}$ after alum addition increased 12 times (approximately) during October to December 1998. The difference (between raw water and after alum addition) in total $\mathrm{Al}$ was $1182 \mu \mathrm{g} / \ell$ less during October - December 1998 study period than September - November 1997 (Tables 6 and 7). A reduction in the applied alum dose during October to December 1998 $(55 \mathrm{mg} / \ell)$ compared to September to November $1997(70 \mathrm{mg} / \ell)$ was responsible for the decrease in total Al. During October to December 1998 alum addition nearly increased three times the inorganically bound $\mathrm{Al}$ (from the raw water level of $14 \mu \mathrm{g} / \ell$ to $39 \mu \mathrm{g} / \ell$ at the point of alum addition) and such an increase remained relatively constant through the rest of the treatment plant (Table 7).

\section{Al speciation - A comparison}

Inorganically- and organically-bound Al levels at BPWTP (Tables 6 and 7) indicated that:

- alum addition increased inorganically-bound dissolved $\mathrm{Al}$ during October to December 1998 but not in September to November 1997;

- inorganically-bound $\mathrm{Al}$ thus formed was removed by sand filtration (approximately 10\%), implying that fine Al hydroxide flocs that leave from clarifier are captured by the sand filtration leading to the removal of inorganically-bound $\mathrm{Al}$;

- organic $\mathrm{Al}$ was the dominant form present in the dissolved $\mathrm{Al}$ during September to November 1997 whereas there was a shift in this condition, i.e. during October to December 1998, inorganic $\mathrm{Al}$ dominated in dissolved $\mathrm{Al}$; and

- colloidal bound Al at clarifier was $15 \mu \mathrm{g} / \ell$ higher during September to November 1997 compared to October to December 1998 (Tables 6 and 7). 
However, such colloidal $\mathrm{Al}$ (over all) formed was removed largely during the subsequent unit processes, namely through filters which reduced their concentration in treated water to less than $5 \mu \mathrm{g} / \ell$ (Table 4).

Al speciation study at the BPWTP (overall) indicated that:

- raw water total $\mathrm{Al}$ varied considerably;

- as expected, alum addition increased total Al levels;

- total, filterable (suspended) and particulate $\mathrm{Al}$ formed due to the use of alum was subsequently removed by clarifier and filtration (more than 90\%); and

- particulate $\mathrm{Al}$ was the dominant species of total Al.

\section{Role of GAC in dissolved Al removal at BPWTP}

Figure 4 shows the percentage removals of particulate and dissolved $\mathrm{Al}$ at clarifier, sand filters and GAC units during September to November 1997 Al characterisation study period. As shown in Fig. 4, there was not much dissolved $\mathrm{Al}$ removal (less than 10\%) by clarifiers and sand filters, respectively. Comparison of mean dissolved and organic Al values between sand - filtered effluent and GAC-filtered effluent showed that GAC was capable of removing $33 \%$ dissolved $\mathrm{Al}$ (Table 6 and Fig. 4). From data given in Table 6, it was calculated that $37 \%$ of the organic form of $\mathrm{Al}$ was removed by GAC unit.

Figure 5 shows the percentage removal of particulate and dissolved $\mathrm{Al}$ levels at clarifier, sand filters and GAC units during October to December 1998. As shown in Fig. 5, there was not much dissolved Al removal (less than 10\%) at all stages, namely at clarifier, sand filters and GAC filtration. During both study periods, it was observed that GAC was capable of removing the organic fraction of dissolved Al. However, total dissolved Al removal during September to November 1997 (33\%) was higher than October to December 1998 (9\%) (Figs. 4 and 5). The difference in dissolved $\mathrm{Al}$ removal capability of GAC was due mainly to the composition of dissolved Al, i.e. during September to November 1997 dissolved $\mathrm{Al}$ was dominated by organic Al, whereas during October-December 1998 inorganically-bound $\mathrm{Al}$ was the dominant fraction of dissolved Al (Tables 6 and 7). This implies that GAC is capable of removing efficiently organic $\mathrm{Al}$, but not inorganically bound Al.

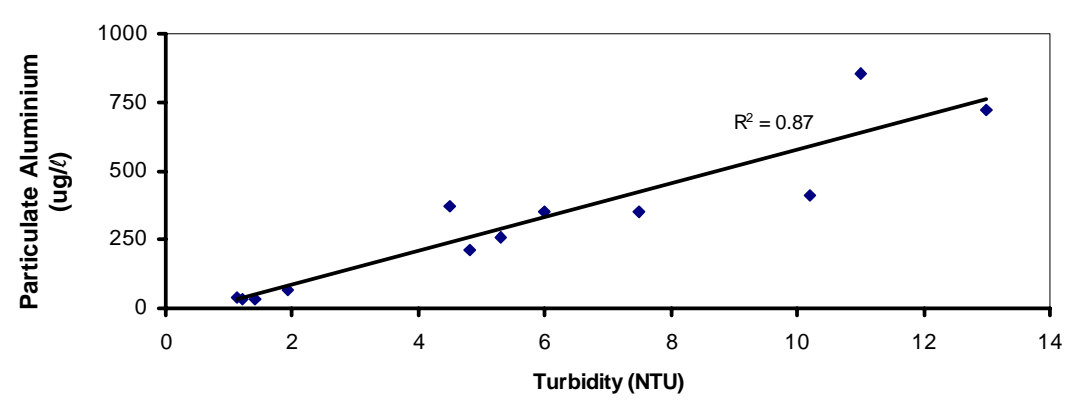

\section{Residual aluminium at BPWTP}

Residual $\mathrm{Al}$ consists of particulate and dissolved forms of $\mathrm{Al}$ present in treated waters and enters into the water distribution system. Reduction in residual $\mathrm{Al}$, as far as possible, would eliminate post-precipitation of $\mathrm{Al}$ in the form of $\mathrm{Al}(\mathrm{OH})_{3}$ during the distribution of the treated water, and reduction of residual $\mathrm{Al}$ would also enhance the quality of the treated water.

Aluminium speciation results (overall) of treated water supplied to Regina (clear well, Regina, Table 4) indicated that the residual $\mathrm{Al}$ consisted of $33 \%$ particulate $\mathrm{Al}$. Speciation of dissolved $\mathrm{Al}$ into organic/inorganic $\mathrm{Al}$ differed considerably between the two $\mathrm{Al}$ characterisation periods. During September to November 1997, dissolved Al present in the clear well water of Regina was $76 \%$ in organic form. It was observed that the organic form of $\mathrm{Al}$ was the dominant form in dissolved Al during September to November 1997 (Table 6). During October to December 1998, dissolved Al speciation of clear well of Regina showed that organically-bound

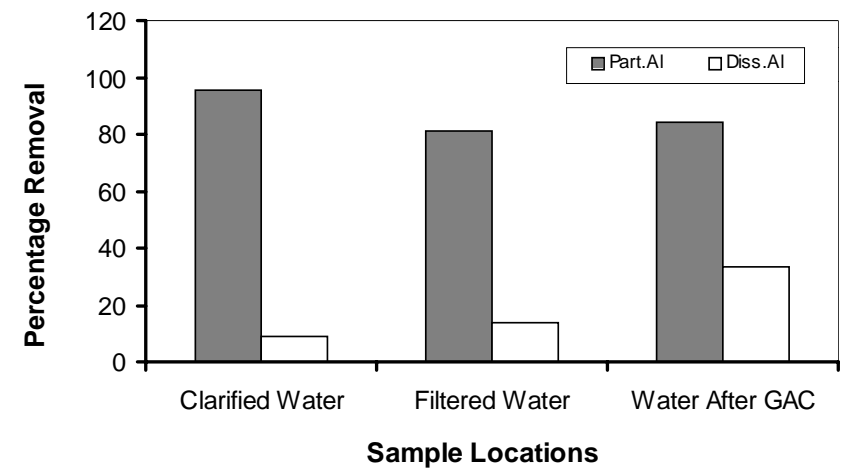

Figure 4

Particulate and dissolved Al removals at BPWTP during September to November 1997

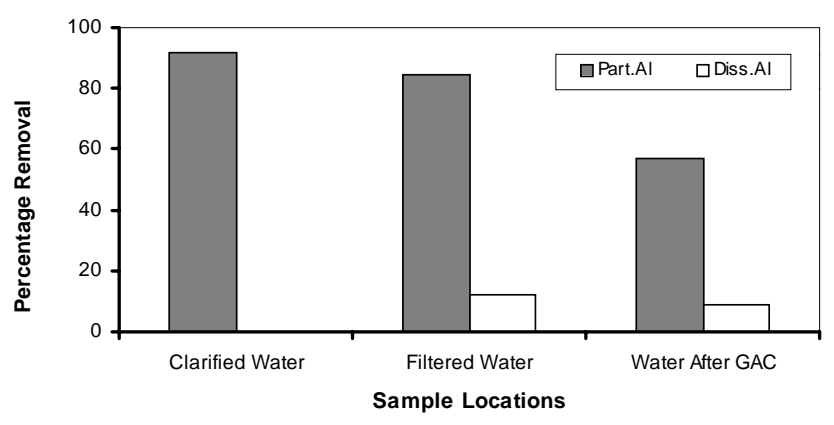

Figure 5

Particulate and dissolved Al removals at BPWTP during October to December 1998
Figure 6

Mean monthly average particulate Al vs. turbidity (raw water) for 1996 to 1998

Al was only $17.5 \%$, whereas inorganically-bound $\mathrm{Al}$ was $82.5 \%$, indicating a shift in the distribution of organic/inorganic $\mathrm{Al}$ in dissolved Al speciation, compared to the distribution of organic/ inorganic Al observed during September to November 1997 (Table 7). Aluminium characterisation studies demonstrated that particulate $\mathrm{Al}$ was a major species present in residual $\mathrm{Al}$ in treated waters at BPWTP and it is likely that both organic and inorganic dissolved species of $\mathrm{Al}$ could equally dominate in residual $\mathrm{Al}$.

Particulate $\mathrm{Al}$ is derived mostly from turbidity-causing substances, and organic $\mathrm{Al}$ is the result of complexation of dissolved $\mathrm{Al}$ with dissolved organic matter. Data relating to mean monthly average values of raw water turbidity (NTU) and raw water particulate $\mathrm{Al}$ (for the year 1996, 1997 and 1998) were analysed by linear regression as shown in Fig. 6. Particulate Al correlated well 
$\left(\mathrm{R}^{2}=0.87\right)$ with turbidity. Raw water dissolved organic carbon of $8.4 \mathrm{mg} / \ell$ was reduced to $3.9 \mathrm{mg} / \ell$ in treated water after treatment during September to November 1997, resulting in $53 \%$ of dissolved organic carbon removal. The remaining $47 \%$ of the dissolved organic carbon available would combine with $\mathrm{Al}$ to give dissolved Al complexes in the form of organic Al. Even though a very similar DOC removal was observed $(8.4 \mathrm{mg} / \ell$ to $5.3 \mathrm{mg} / \ell ; 37 \%$ removal) (Table 3) during October to December 1998, organic Al was not the dominant form of dissolved $\mathrm{Al}$, rather inorganic $\mathrm{Al}$ was the dominant form. Tables 6 and 7 show that raw water organic Al values in 1997 and 1998 were fairly similar. The big difference in 1997 occurred in the prechlorination and alum (addition) processes for reasons unknown. $\mathrm{pH}$ variations could be the likely cause of the differences observed. In spite of the fact that dissolved $\mathrm{Al}$ levels were less than $50 \mu \mathrm{g} / \ell$, efficient removal of dissolved organic carbon and proper usage of alum dose could further reduce the dissolved $\mathrm{Al}$ in the treated water. Recently $100 \mu \mathrm{g} / \ell$ has been recommended as an operational - guideline value (for conventional water treatment plants) for $\mathrm{Al}$ in drinking water (Health Canada, 1999). Al speciation studies at the BPWTP indicated that the Al levels were less than the guideline value of $100 \mu \mathrm{g} / \ell$.

\section{Conclusions}

Characterisation of $\mathrm{Al}$ at BPWTP showed that raw lake water total Al concentrations were highly variable and that the filterable (suspended) form of $\mathrm{Al}$ was the predominant species of raw water total Al. Organically, $\mathrm{Al}$ appeared to be the predominant species of dissolved Al through (raw to treated) the BPWTP during September to November 1997. However, there was a shift in this condition during October to December 1998, i.e., inorganic Al dominated in dissolved Al. Alum addition ( 55 to $70 \mathrm{mg} / \ell$ ) efficiently coagulated filterable Al. The clarifier removed those in the form of $\mathrm{Al}(\mathrm{OH})_{3}$ precipitate. Alum floc was effectively removed during clarification.

The present study showed that total Al after (liquid) alum treatment did not increase in treated water at BPWTP mostly because:

- alum coagulation was practised at $\mathrm{pH} 7$, at which the $\mathrm{Al}$ is least soluble;

- clarifier and filtration units removed particulate Al efficiently (the major species of total $\mathrm{Al}$ ); and

- GAC was also capable of removing part of the organic dissolved $\mathrm{Al}$;

- total dissolved $\mathrm{Al}$ itself was less than $50 \mu \mathrm{g} / \ell$ all through the plant; and

- turbidity and dissolved organic carbon of the raw water influenced the applied alum dose.

\section{Acknowledgements}

The authors would like to thank Dr. Joe Bergman, Assistant Plant Superintendent/Plant Chemist of BPWTP and Mr. B. Kardash,
Senior Laboratory Technician of BPWTP Laboratory for their help and advice in the study. The first author thanks the Faculty of Graduate Studies and Research for partial financial support.

\section{References}

ALLAN PK (1997) A Method for the Speciation of Aluminum in Natural Surface Waters. Ph.D. Thesis, Univ. of Massachusetts, Amherst, USA.

AWWA COMMITTEE REPORT (1993) Research needs for inorganic contaminants. J. AWWA 85 (5)107 -113.

BENES P, GJESSING ET and STEINNES E (1976) In situ dialysis for the determination of the state of trace elements in natural waters. Water Res. 10 711-717.

BEREND K and TROUWBORST T (1999) Cement mortar pipes as a source of aluminum. J. AWWA 91 (7) 91-100.

BERUBE D and BRULE DG (1994) An Atlantic Canada shallow well drinking water study: First phase results of a national survey for major and trace elements and aluminum speciation. 6th Natl. Conf. on Drinking Water. Victoria, BC, Canada. 307-321.

BLOOMPR and ERICHSM (1989) The quantitation of aqueous aluminum. In: Sposito S (ed.) Environmental Chemistry of Aluminum. CRC Press, Boca Raton, Fla. 1-27.

DRISCOLL CT and LETTERMAN RD (1987) Residual Aluminum in Filtered Water. AWWARF and AWWA, Denver, Colorado.

DRISCOLL CT and LETTERMAN RD (1988) Chemistry and fate of Al III in treated drinking water. J. Environ. Eng. Div. ACSE. 114 (1) 21-37.

DRISCOLL CT and LETTERMAN RD (1995) Factors regulating residual Al concentrations in treated waters. Environmetrics 6 287-309.

FLORENCE TM and BATLEY GE (1980) Chemical speciation in natural waters. CRC Crit. Rev. Anal. Chem. 9 (3) 219-296

HEALTH CANADA (1996) Aluminum in Drinking Water (document for public comment). 1-44. Prepared by the Federal-Provincial Subcommittee on Drinking Water, Ottawa, Ontario, Canada. HEALTH CANADA (1999) It is Your Health - Aluminum and Human Health. A Health Canada document for public comment (www.healthcanada.net) dated December 1, 1999.

LETTERMAN RD and DRISCOLL CT (1994) Control of Residual Aluminum in Filtered Water. AWWARF and AWWA, Denver, Colorado.

McLACHLAN DR, KRUCK TP, LUKIU WJ and KRISHNAN SS (1991) Would decreased aluminum ingestion reduce the incidence of Alzheimer's disease? Can. Med. Assoc. J. 145 (7) 796-804.

MILLER RG, KOPFLER FC, KETLY KC, STOBER JA and ULMER NS (1984) The occurrence of aluminum in drinking water. J. AWWA 76 (1) 84-91.

PARKINSON IS, GEEST TG, WARD MK, FAWCETT RWP and KERR DNS (1979) Fracturing dialysis osteodystrophy and dialysis encephalopathy. An epidemiological survey. The Lancet. I 406-409.

SRINIVASAN PT, VIRARAGHAVAN T and SUBRAMANIAN KS (2000) Method development for drinking water aluminum measurement using graphite furnace atomic absorption spectrophotometer. Am. Lab. 32 (3) 76-91.

STANDARD METHODS (1995) Standards Methods for the Examination of Water and Wastewater $\left(19^{\text {th }}\right.$ edn.) American Public Health Association, Washington, D.C.

VAN BENSCHOTEN JE and EDZWALD JK (1990) Measuring aluminum during water treatment: Methodology and application. J. AWWA 82 (5) 71-79. 